\title{
Is Pandemic a Class-Ridden? An Appraisal from New York City
}

\author{
Abin Ojha ${ }^{1}$ \\ York College, CUNY, Queens, New York
}

\begin{abstract}
The virus does not see race, caste, class, gender, region, religion, language, and border." This is a ubiquitous saying, but pandemics hit the vulnerable sections of the society the hardest, which has been proved many times in history. Today, this fact is verified again. Covid-19 attacks the poor and the marginalized sections of the community severely; these groups have had more infected and lost more lives than others. Why do diseases impact the poor and marginal sections of the community more than other groups? The template answer says that this - because of their ghettoized living conditions, lack of hygienic foods, and poor health conditions and medical facilities. This article tries to assess why the poor and working-class suffers more from such pandemics from a sociological lens. Various quantitative information and qualitative understandings have been apprised in the article to assess why the poor and working-class suffers more in such pandemics. Various newspaper articles and research work were reviewed to analyze facts and situations. This article reflected the situation of minorities amid the COVID-19 pandemic and the postpandemic situation. The discussion and conclusion derived in the paper may not be generalized.
\end{abstract}

Keywords: class, economic inequality, informal sector, marginalized, pandemic, segregation.

\section{Introduction}

The first case of the COVID-19 was confirmed in China on November 17, 2019. At that time, nobody thought that this virus would become this deadly. The developed Western countries simply viewed it as being like the flu and believed it would not damage them. Instead of taking precautionary measures, they enjoyed the virus's cruelty in China, mocking Coronavirus as the Chinese-virus. Most Western leaders ignored the reality of the virus until it hit them hard. Coronavirus originated in China then traveled to Europe, American, and has now reached every corner of the world. Today, Covid-19 has become a global health threat and created an economic crisis and political instability in many countries.

The pandemic was not a sudden attack on the other countries like China had. They had plenty of time to take measures to control its spread. For instance, the United States had almost two months to take preventive methods between the first case confirmed in China and Washington State. America failed here; all developed countries failed there. Either their ignorance or inability negatively impacts their ability to control the outbreak. As a result, the virus walloped them. They are now paying for it, with an enormous loss of life and a severe economic downturn.

\footnotetext{
${ }^{1}$ Correspondent author e-mail: abinojha@gmail.com
} 
Consequently, by March 26, 2020, the United States of American reported the most COVID-19 cases in the world. Today, the United States has the highest number of infections and fatalities. The United States (August 6, 2020) has more than 25\% of total global cases of COVID19 and 22\% death of total death (Garbe et al., 2020; John Hopkins, 2020). As a result, everything paused; the economy begins shrinking, and people are losing their jobs. Covid-19 is not only causing a health crisis, but it is also destroying the global economy and threatening all of humanity.

The first case of COVID in New York was confirmed on March 1, 2020, but the New York Times (Cary \& Glanz, 2020) claimed there could have been thousands of infections in New York City before the first case was confirmed. According to John Hopkins University and Medicine's online data (August 6, 2020), more than 4.8 million Americans have confirmed COVID infections, and of them, more than 158,606 have lost their lives. So far, New York has had 423,000 confirmed cases, and over 32,000 New Yorkers lost their lives due to COVID infection. In the last few weeks, the cases in New York are declining, but, in overall America, COVID cases are still surging.

The following sections analyze the COVID issues from sociological perspectives. New York is hit-hard by the COVID, which was beyond the expectations. Nobody was expecting New York to become an epicenter of Coronavirus. However, the reality is just the opposite of expectations. For almost two months from the second week of March until the third week of May, it was in a war with an unseen enemy. Hundreds of thousands of New Yorkers were wounded in the war; thousands of them lost their lives. What group was infected more? Who lost more lives? The answer is, as expected, minority groups. As an invisible enemy, either put them in a significant health crisis or took away their lives. Why were minorities infected at a higher rate? Why did the government's measures (stay at home, or shutting down the non-essential sectors) fail to control the spread of the virus among them?

\section{Conceptual Underpinning}

The Center for Disease Control (CDC, 2020) argued that long-standing systemic health and social inequalities in the United States have put may people from racial and ethnic minority groups at a higher risk of being infected and dying from the pandemics.

Burton et al. (2020) wrote that the United States has a long history of resource inequalities, particularly for ethnic minority backgrounds. Even in the current $21^{\text {st }}$ century, the United States is entrenched in health care disparities and the social determinism of health. It was reflected during the COVID-19 pandemic. This pandemic not only affected directly to their health, but stay-at-home mandated have exacerbated major problems among minority and low socioeconomic status populations. "When COVID-19 was declared a pandemic - we see disproportionate effects in severity and mortality in minorities diagnosed with Covid-19" (p. 3). Bonillia-Silva (2020) pointed out that essential workers are more exposed to the virus and are disproportionately workers of the colors. "In our racialized class structure, Black and Brown workers to be in jobs more exposed to COVID-19 than Whites" (p. 4). In this article, we are not debating why the people of color overrepresented in low-paying dangerous work? We discuss what went wrong and why there is a differential in infection and mortality rates of COVID-19 among the different classes.

According to APM Research Lab Staff (2020) data, by May 19, 92,000 Americans had lost their lives due to the virus. The latest overall COVID-19 mortality rate for Black Americans is 2.4 times as high as $r$ whites' rate. APM Research Lab claimed that 1 in 2,000 Black Americans died or 50.3 per 100,000, and 1 in 4,300 Asian and Latino Americans have died, or at 22.7 and 22.9 per 100,000, and 1 in 4,700 White Americans have died at the rate of 20.7 per 100,000. The research notes that "If they had died of COVID-19 at the same rate as White Americans, about 12,000 Black Americans, 1,300 Latino Americans, and 300 Asian Americans still are alive" (p. 1). Sur (2020) 
gives a similar figure from India, 61 lower caste people died for every 1,000 fatalities in the community; for the upper caste, it was 19 for 1,000 .

NYC Health Department's data reflects the same statistics. Death rates per 100,000 New Yorkers, Asian/Pacific Islander is 100.88, White 106.45, Black or African American 214.10, and Hispanic/Latino 224.48. NYC Health Department s data further reveals that the death rate is higher among the poor. The death rates per 100,000 in low poor is 103.45 , medium poor is 166.75 , high poor 209.42, and very high poor is 240.16. (NYC Health Department, 2020). Woolhandler and Himmelstein (2020) opined four decades of neoliberal health policies had left the United States with a health care systems that prioritized the profit of large corporate actors, denies needed cares to 10 of millions, and ill-prepared to address to COVID-19 as the leading cause of the impaired performance of the United States against the Coronavirus. Racial disparities such as persisting social inequality, including poverty and racial discrimination and spatial exclusion, have dismantled community capacity. "As a result, residents in highly segregated, disfranchised neighborhoods are disproportionately exposed to social and health risks" (Kim \& Bostwick, 2020, p. 511). The United Nations Human Rights Office of the High Commissioner (2020) also declared that the COVID-19 crisis and its impact are disproportionately affecting marginalized racial and ethnic communities and population groups.

Why did COVID hit the minority groups or the weaker section of the community the hardest? Most people share the common opinion that diseases impact low-income and minority groups at higher rates because of their underlying medical conditions, unhealthy diets, and lack of access to quality medical care. To some extent, these assumptions are correct. However, they are not the entire answer. To determine why COVID is so cruel against minorities and the more underprivileged sections of the community. A sociological lens must be used to assess various social, economic, and cultural aspects.

\section{Methods}

This article is descriptive. Various information and data fact used in this article are derived from different published sources. To assess the pandemic's impact, especially among the minorities and working-class, cases of COVID-19 in New York City have been referred. The article primarily examined the early spike of Coronavirus (March-May 2020) in New York City. Therefore, the discussions, findings, and conclusions derived from this article may not be generalized elsewhere. The article seeks to assess; why minorities hit hard by the COVID-19? and What would be the post-pandemic situation among the minorities? Various demographic, economic, and social aspects of minorities in New York City are assessed to answer these questions. Some of the social problems that arise amid the pandemic and may arise post-pandemic are reflected in the article. Overall, the article re-evaluates the situation of minorities/working-class in New York City.

\section{Demography, Occupation, Unemployment, and Poverty in the United States by Race}

This paper examines race wise the impacts of Covid-19 concerning races and assesses the causes of differential impacts. Therefore, it is vital to review the demographic characters of the area. The demography of the United States and New York is reviewed.

The total population of the United States is about 328 million. Of which, the Whites population comprise $76.5 \%$, followed by Hispanics and Latinos 18.3\%, Black or African Americans 13.4\%, Asians 5.9\% and American Indians and Alaska Natives 1.3\%, Native Hawaiians and other Pacific Islanders 0.2 \%. New York state has about 19.45 million people. It is composed 
of 69.9\% Whites, $19.2 \%$ Hispanics and Latinos, 17.6\% Black or African Americans, 9.0\% Asians, 1.0\% American Indians and Alaska Natives, $0.1 \%$ Native Hawaiians, and other Pacific Islanders, and $2.6 \%$ two or more races (U.S. Census Bureau, 2019).

According to the U.S. Bureau of Labor Statistics Report (U.S. BLS, 2019), the United States' overall unemployment rate is $3.9 \%$. The unemployment rate is higher among the American Indians and Alaska Native (6.6\%), followed by Black or African Americans (6.5\%), Hispanics (4.7\%), and Native Hawaiians and Other Pacific Islanders (5.3\%), and Whites (3.5\%). The unemployment rate is lower among Asian Americans (3.0\%). Among the employed population, $54 \%$ of Asians are employed in management, professional and related occupations in the highest paying occupation or White-collar jobs followed by White $41 \%$, Black $31 \%$, and Hispanic $22 \%$. This data shows that many Black and Hispanic people are working in blue-collar jobs in natural resources, construction, maintenance, and service sectors.

Eaves and Al-Hindi (2020) opined that the essential workers, many of whom are racialized people, immigrants, and low wealth people whose occupations include domestic work, janitorial work, grocery workers, and in-home-health care, risk infecting their families for precarious employments. Household income instability forced these marginalized workers to continue their work amid the pandemic. Laster Pirtle (2020) argued that racial capitalism as a fundamental cause of racial and socioeconomic inequalities with the novel Coronavirus pandemic in the United States. "Racism and capitalism mutually construct harmful social conditions that fundamentally shape COVID-19 (pp 1)." For instance, people with high socioeconomic status secure a higher set of knowledge, power, money, power, prestige, and beneficial social connections, all of which can minimize the consequences of the disease (Aliyyah et al., 2020; Link \& Phelan, 1995). The socioeconomic status and poverty of the people and exposure to the virus correlated positively. The poverty rate in the United States in 2018 was $11.8 \%$. According to the 2018 census data, $25.4 \%$ of Native Americans, $20.8 \%$ of African Americans, $17.6 \%$ Hispanics, $10.1 \%$ Whites, and $10.1 \%$ of Asians live under the poverty line (Semega et al., 2019:13).

From the above facts, both the unemployment and poverty rates both higher among minorities. Among the employed population, African Americans and Hispanics and Latinos are mostly employed in the lowest paying blue-collar jobs. Most are essential workers. In this context, pertinent questions include how the government 's policy to shut-down non-essential business and order people to stay at home, works for these essential workers? How are living from day-to-day paychecks able to abide by the stay at home or lockdown orders? Is it even possible for these groups to maintain self-isolation and keep physical distance in tiny shared apartments? What measures did the government propose to address various problems faced by the classes of society? What will be the post-pandemic situation? These questions are the issues for the debate. Let us begin with the appraisal of why ethnic minorities exposed more to the virus?

\section{Geospatial Segregation—Living Conditions, Housings, and Facilities}

All the experts throughout the world have a common understanding of a COVID-19; it is among the more contagious viruses that have existed so far. Social distancing and self-isolation are only the means to control this virus until a vaccine or medication is available. A crucial question arises: Is it possible to maintain self-isolation or self-quarantine for the working-class in New York City, who live in shared apartments? The answer is straightforward; it is not. For instance, in the beginning, most of the working-class with confirmed cases, having mild symptoms, have been sent from the hospitals to their homes to self-quarantine. Practically speaking, it is impossible to maintain self-isolation, living in a shared apartment with limited facilities. As a result, more people get infected. 
The government did not think of this problem of the working poor at the beginning. If there is not enough space in the hospitals for the confirmed mild cases of COVID-19, the government could keep those with mild symptoms cases in the schools or other public spaces under regular health monitoring until they recovered. The situation of New York City would not have been that worst. That would have saved thousands of lives and controlled the infections. When the government of New York realized this fact, it was too late; many had already gotten the viruses. If the government had addressed this issue earlier, it would have saved thousands of lives.

The differences in housings and facilities between the working-class and middle or upperclass must be examined. There is clear geospatial segregation between these classes in housing and facilities. Mostly, the working-class find their housing in an apartment nearby central business districts because it is easier for them to commute to work and home. As a result, these districts become densely crowded. For this group, following and maintaining the parameters of health emergencies are nearly possible. For people living in sharing apartments, a long self-isolation or quarantine is like self-imprisonment.

Housing and facilities in the house are fundamental determinants for the spread of contagious diseases or viruses. The marginal section of the society has inadequate housing and poor living conditions with limited facilities in the house. As a result, measures like staying at home, lockdown, self-quarantine, and so forth taken to control the spread of such contagious viruses are less effective. Let us find the experience of one immigrant who lives in New York City in a shared apartment.

An immigrant in his forty, who lost his friend in his shared apartment in New York City, now just recovered from Coronavirus, shared his plight amid this pandemic. His roommate was tested positive, and the hospital asked him to stay in self-isolation at home. He was living with his COVID positive friend in the same apartment. He said he could not maintain distance and stay safe from his apartment-mate in a tiny apartment with a shared kitchen and bathroom. He became infected, sadly his roommate died, but thankfully he won the battle against COVID-19. He is only a representative character. This situation is common to many immigrants living and poor class families in the New York metro area.

In contrast, the middle or upper-class lives in a single-family unit having enough spaces, facilities, and backyards. Their living is segregated and isolated. They use a private vehicle for transportation. As a result, they do not have a problem with distance maintenance and self-isolation or quarantine, which reduced their likelihood of becoming infected.

People living in multi-story apartment buildings could maintain a social distance because of housing patterns and the facilities (the elevator, public space, public facilities) they use. From an urban planning perspective, vertical planning could be the best housing alternatives in crowded megacities. However, this pandemic might conclude that horizontal planning in the suburbs would be best for all. Such horizontal living is impossible in primate cities like New York. In the new city development, the planners have to prioritize the horizontal living; on the one hand, it offers a singlefamily house to the people, and on the other hand, it contributes to suburbia or rural development.

The United States still entrenched in disparities of health care coverage and access to health care facilities. Before the Covid-19 pandemic, about 27.5 million Americans had no health insurance (Frazee, 2020). Most groups of color reminded ore likely to be uninsured compared to whites (Walter-McCabe, 2020). A higher prevalence of circulatory diseases among those classified as poor versus not poor is $13.5 \%$ vs. $10.9 \%$ (Burton et al., 2020).

Artiga et al. (2020) found that blacks remained 1.5 times more likely to be uninsured than Whites, and the Hispanic uninsured rate was over 2.5 times higher than the rate for whites in 2018. In 2018, the uninsured rate for the poor $(<100 \%$ of the Federal Poverty Level, FPP) individuals 
Ojha, A.

were four times higher than the rate for those at the higher incomes (400\% or above FPP) (30.3\% vs. 6.0\%). It is evident that low-income groups more likely to be uninsured and may have had underlying conditions. People with no insurance tend to delay in tests and treatment, which increases the virus's spread. Around 5.4\% of New Yorkers had no health insurance in 2019 (NYS Health Foundation, 2019).

\section{Economic Inequalities - Nature of Work and Life on Paychecks}

New York State closed all non-essential business form on March 22, 2020, and asked people to stay home. But essential business remained open, and essential workers have to work. According to the U.S. BLS Report (2019), a significant number of the Black (41\%) and Hispanic (31\%) people were working in Blue-collar jobs. "Employed Black and Hispanic men also were more likely than White and Asian men to work in production, transportation, and material moving occupations (pp 5)." For example, the low-income worker, grocery-clerk, can neither work from home nor quit the job.

Another immigrant (39) who lives in New York City and works in a grocery store, said that he is working all day during the pandemic. He said, "I am an essential worker; if I quit my job voluntarily, I am not eligible for Pandemic Unemployment Assistance offered by the government." He further said, "I live on a day to day paycheck, and I can't imagine about rent and food without work." He said he uses public transportation to commute from home to work, which has kept him at a higher risk of infection.

Anderson (2016) noted that one-in-ten Americans (11\%) prefer to take public transportation daily or weekly. Among urban residents, $27 \%$ of Hispanics and $34 \%$ of blacks use public transit daily or weekly, compared with only $14 \%$ of whites. Most blacks, Hispanics, and other minorities use more public transit because they live in nearby central business district areas. Whites workers a lot less likely to take public transportation than other races (Goldmark, 2012).

The New York subway has a daily ridership of approximately 5.5 million, and an annual ridership in 2019 is roughly 1.67 billion (MTA, 2019). Goldmark (2012) found that in the New York metro area, $61.9 \%$ of the workforce is white; among them, only $47.2 \%$ use public transportation for the home to work. Maciag (2014) reported that the median income of the public transportation riders in New York City is $\$ 35,350$ and, $8.7 \%$ of public transportation commuters live under poverty. He further concluded that public transportation commuters tend to be disproportionately poorer than those driving to work.

Not only the commuters, but the bus and subway workers in New York City have also been hit hard by the COVID-19. More than 100 MTA workers died, and more than 60,000 either diagnosed with COVID-19 or self-quarantined because they have symptoms. Who works for the MTA? The answer is obvious-blacks, Hispanics, and Latinos. They account for more than $60 \%$ of the agency's workforce. Black people are overrepresented in the New York MTA, $46 \%$ of the city's transportation workers (Scott, 2020).

The government's steps of closing-down except for the essential services, to control the spread of the virus have put working-class and minority groups with blue-collar jobs at higher risk of infection. According to Mays and Newman's (2020) article, "75\% of frontline workers in the New York City-grocery clerks, bus and train operators, Janitors, and childcare staffs-are minorities. More than $60 \%$ of people who work as cleaners are Latino, and more than $40 \%$ of transit employees are Black."2

\footnotetext{
${ }^{2}$ https://www.nytimes.com/2020/04/08/nyregion/coronavirus-race-deaths.html
} 
Minorities are essential business workers; thus, the State' s policy "stay at home" and "closing of the city" to control the spread of COVID-19 did not work well for them. Minorities live on day-to-day paychecks and work in the essential businesses that are entitled to continue their work. These individuals, described as essential workers, kept leaving their homes. How much a person's risks of infection hinges on class. Most of the city's essential works; as a result, they are hard-hit by the virus.

Leigh and Kelly (2020) found that low-income minorities left homes at the height of the pandemic. They tracked the cell phones of the people living in poor zip codes in New York City. Cell phone data indicates about $8 \%$ of people regularly left home to work late March to April. Leigh and Kelly's research for abc7ny.com shows that in an area with the highest share of racial/ethnic minorities ( $95 \%$ and up) or living in poverty ( $35 \%$ and up), people are more likely to leave home for work amid the pandemic. "The data shows people in $88 \%$ of low-income neighborhoods, and $84 \%$ of predominantly minority neighborhoods continued to work outside of the home at a rate higher than the citywide average, which is about $8 \% . " 3$

Unfortunately, they are kept on the backline in the regular days, always and in all the ways. However, during the pandemic, these back-liners have become front-liners and essential workers. They continued their work amid the pandemic, putting their lives on the stake. As a result, minorities and more underprivileged sections of the community were more infected by the virus. Hundreds of thousands of people got the virus, and thousands of families lost their beloved ones. Lall \& Wahba (2020) claimed that economic geography, not the physical geography, determines contagion risks. They compared two neighborhoods in New York City, poor and the wealthier neighborhoods, and compared their density. The crowded and blustering immigrant neighborhood of Jackson Heights was worst affected by the virus than Chelsea's wealthiest neighborhood. The COVID-19 case was as high as 4,125 per 100,000 residents in the zip code 11368 (Corona), and in the wealthier 10011 (Chelsea) zip code was much lower at 925 per 100,000 residents. The neighborhood of West Queens is not the densest compare to Chelsea, but the infection rate is way higher than Chelsea. Why did Queens have more infections? Lall and Wahba claimed cramped quarters, multi-generational families in the same apartments, and residents have no option. They have to go out every day in search of employment or services. The government s policy of pausing the work and even locking down the nation did not impact them. However, even under normal circumstances, government policy has merely benefited such groups.

\section{Discussions}

The COVID-19 pandemic has become more than a disease. From a pathological perspective, it is a deadly contagious disease that caused a global human health crisis. From a sociological lens, it is more than a disease, threatens human life, and leads to various social problems.

In the previous section, we discussed the impact of COVID-19 on the marginal class. It is taking their lives and creating a social situation that damages them for many years. The disease is a cruel agent of a society that breaches the gap between rich and poor, haves and haves-not, and majority and minority. These divisions trigger social problems in society. The following section discusses the social problems among the minorities in the post-COVID 19.

\footnotetext{
${ }^{3}$ https://abc7ny.com/nypd-crime-statistics-new-york-city-coronavirus-nyc/6071137/
} 
Discrimination, domestic violence, suicide, and crime have spiked amid the pandemic. Hate crime has surged. For example, amid the pandemic, hate crime (harassment to assault) against Asian Americans grew in New York. "Indeed, New York City logged 248 complaints of coronavirus discriminations, as about 42\% reported in March and April 2020 explicitly been antiAsian" (Yang, 2020). Yang (2020) wrote that the overall crimes rate in New York City had fallen in 2020, but the hate crime against Asian Americans had risen unexpectedly. Domestic violence and abuse are rising worldwide as a stay at home or lockdown orders imposed by countries limits the people's mobility and forced them to spend more time at home. The belief is that this has led to a surge in domestic violence.

Global News (2020) wrote that New York City had seen a rise of 15\% of reported domestic violence incidents in March and a 30\% increase in April as the New York State (2020) article claimed that there was a $12.0 \%$ increase in intimate partner victimization. Reports from all over the world claim that there has been a significant increase in crimes like burglary, murder, robber, and grand larceny due to stay-at-home or lockdown orders. ABC News (2020) reported that crime in New York City was down 20\% during the last two weeks of March. However, crime, especially theft of money and property for the food, may arise if this stay at home or lockdown continues. Working poor and even lower-middle-class people may suffer from a shortage of money and foodstuffs that may provoke them to commit crimes. These social problems need to be addressed from the concerned authority before it creates another threat to society.

Cohen (2020) asked, "Did you know that your occupation may be all that stands between you and a life of crime?" To respond to how people are involved in the crime after being laid off. She has cited a case for Norway. This country is considered a country with a robust social safety net that makes jobless less painful than in other countries like the United States. According to Cohen's article, 1 million laid-off Norwegians over the age of 15 years, and outof-work people could commit $60 \%$ more property crimes in the year after losing work and have more criminal charges than when they were employed.

According to an International Labour Organization (2020) report, as the pandemic becomes prolonged, the labor market is devastated, and workers in the informal economy and hundreds of millions of enterprises worldwide are at the stake of being out of work. If it continues, 1.6 billion workers in the informal economy, which is nearly half of the global workforce - stand in immediate danger of having their livelihoods destroyed. This pandemic has already witnessed a tremendous global economic crisis and escalated the labor market (Tarman, 2020). The informal sector is the primary source of employment for the working poor and working-class. The livelihood of this section would become more vulnerable after the pandemic.

Prominent sociologist Emile Durkheim argued that modern society is organized by organic solidarity, through interdependence. He said that if this solidarity becomes precarious or not hold in position, then the situation may result in anomie among the people. Anomie simply understood as a feeling of disconnection from the standard rules of society. Anomie is caused primarily by psychological stress and frustration, and when people feel that they are worthlessness or in despair. Amid the pandemics, most people are out of jobs, small and medium entrepreneurs have hard times, and the situation of stay at home or national lockdown has mounted loneliness, frustrations, and financial worries. As a result, the rate of suicide is also heightening amid the pandemics. The highest rate of suicide will be recorded among the working poor.

\footnotetext{
${ }^{4}$ https://www.fastcompany.com/90477075/covid-19-layoffs-recession-jobs-research
} 
Bach (2020) states that suicide has previously increased in connection with a significant crisis. He claimed that death by suicide increased during the 1918 Spanish flu, the 2003 SARS outbreak, and even during the 2008 economic recession. Das (2020) wrote that suicide had seen a sharp rise in Kolkata, India, amid the lockdown. Gordon (2020) has estimated that conditions stemming from Coronavirus in the United States could lead to 75,000 deaths from drugs or alcohol abuse and suicide.

Clissold \& et al. (2020), "the risk of acquiring and dying from COVID-19 are greatly increased for BAME (Black, Asian, and Minority Ethnic) groups compared to White ethnic groups ( $p$ p 422)." The BAME is a socio-economically deprived community associated with worse health outcomes. In the time of Coronavirus outbreaks, these communities are more exposed to the virus because of overcrowded households, more inadequate access to healthcare, and higher occupational risk. Black, Hispanics, and Asians make up more than $70 \%$ of the city's essential workers (Goba, 2020). Black and Brown people amid the coronavirus pandemic went to the job then came back home and spread the virus among their family-friends.

Government policy has not helped the daily lives of the marginal and the working poor of the society amid the pandemic of Covid-19. The government policy to shut down the nonessential works or the pandemic relief benefits had not helped the working poor or marginalized. Most of the working poor and more unfortunate sections of society are either essential workers or employed in informal sectors. Stay at home or lockdown measures that the government has taken keep these groups out of work and make day-to-day living challenging.

Incorporated and coordinated policy plays a vital role in combatting national emergencies. During this pandemic, the United States policies at the federal and state levels seem fragile in flattening the Coronavirus's outbreaks. Interactions and coordination between the states and the federal government prior and amid the pandemic were very confusing. "Commentators both decried and praised federalism as the crisis unfolded, the national government faltered in its leadership, and governors moved in different directions in their responses (Mallinson, 2020:1)". The President at the federal level has had different directions, and Governors have had different preparedness at the state level. The confusion and conflicts among the federal, state and local governments to respond to the outbreak on time resulted in a severe attack. If the government at both levels, federal and state, had adopted a coordinated tunnel vision health policy to combat this unseen enemy, the Coronavirus, the story today would have been different.

You (2020) reviewed the South Korean public health policy in response to Covid-19. South Korea endured devastating early outbreaks, and the country flattened the Coronavirus curve without paralyzing the national health system and economic system. South Korea's policy to control the pandemic has emerged as a model to the world. The author pointed out three primary reasons why South Korea's policy response to Covid-19 worked well. First, homogenous cultural and institutional structures helped facilitate an adequate response. "Citizens were willing to sacrifice privacy for surveillance and contact tracing using ICT (p. 5)." Second, timely and proper action from the legislative and executive branches administered prior and amid to pandemic. Third, the public health budget and flexible fiscal management system allowed the South Korean government to provide adequate resources. "The South Korean government and national health insurance program shouldered the full cost of coronavirus testing, quarantine, and treatment for Korean citizens and noncitizens (p. 5)." You's work concluded that citizen's support and coordinated/unified efforts of different government tiers could help combat such a pandemic.

CDC (2020) accepted that long-standing systemic racism and social inequality have put many people from racial and ethnic minority groups at increased risk of COVID-19. "Inequities in 
Ojha, A.

the social determinants of health, such as poverty and healthcare access, affecting these groups are interrelated and influence a wide range of health and quality-of-life outcomes and risks, ${ }^{5}$ CDC argued that health equality is essential, and to achieve itall barriers should be removed so that everyone has fair opportunity to be as healthy as possible. Various relief benefits offered by the government have hardly reached the neediest of communities. Instead of getting government relief, they have suffered much, and many lives have been lost. The vulnerable groups' situation becomes more difficult because of their poor economic status and the government's fragile social safety nets. Economic hardship for daily livelihood is mounting each day.

\section{Conclusions}

In conclusion, economic geography, entrenched exclusion and discrimination, house and housing facilities, work and nature of work, public space and facilities, health and access to health care, and fragile government policies all at a time were not favorable to the poor and working class. As a result, they suffered much. These sections suffer much even after the pandemic. How long will they suffer from both disease threats and economic challenges? How will the world address the problems of minorities and weaker sections in the post-COVID days? It has become a matter of interest and requires more focus attention. However, the pandemic is not permanent, but its impact on the poor class's livelihood may remain long.

\section{Funding Details}

This work was not supported by any funding grants or awarding bodies.

\section{Disclosure Statement}

There is no conflict of interest or benefit that has arisen from this article's direct application.

\section{References}

ABC News. (2020, April 2). Coronavirus news: NYPD reports $20 \%$ drop in crime during COVID19 emergency. ABC News. https://abc7ny.com/nypd-crime-statistics-new-york-citycoronavirus-nyc/6071137/

Aliyyah, R. R., Rachmadtullah, R., Samsudin, A., Syaodih, E., Nurtanto, M., \& Tambunan, A. R. S. (2020). The Perceptions of Primary School Teachers of Online Learning during the COVID-19 Pandemic Period: A Case Study in Indonesia. Journal of Ethnic and Cultural Studies, 7(2), 90-109. http://dx.doi.org/10.29333/ejecs/388

Anderson, M. (2016, April 16). Who relies on public transit in the U.S? Pew Research Center. https://www.pewresearch.org/fact-tank/2016/04/07/who-relies-on-public-transit-in-the-us/

APM Research Lab Staff. (2020, May 20). The color of Corona Virus: COVID-19 death by race and ethnicity in the U.S. APM Research Lab. https://www.apmresearchlab.org/covid/deaths-by-race

Artiga, S., Orgera, K., \& Pham, O. (2020, March). Disparities in health and health care: Five key questions and answers. http://files.kff.org/attachment/Issue-Brief-Disparities-in-Healthand-Health-Care-Five-Key-Questions-and-Answers.pdf

\footnotetext{
${ }^{5}$ https://www.cdc.gov/coronavirus/2019-ncov/community/health-equity/race-ethnicity.html
} 
Bach, T. (2020, May 22). Will suicide rise because of Covid-19? U.S. News. https://www.usnews.com/news/healthiest-communities/articles/2020-05-22/experts-warnof-a-surge-of-suicides-tied-to-the-coronavirus-pandemic

Bonillia-Silva, E. (2020). Color-blind racism in pandemic time. Sociology of Race and Ethnicity, OO(0), 1-12. https://doi.org/10.1177/2332649220941024

Burton, E. C., Bennett, D. H., \& Burton, L. M. (2020). COVID-19: Health disparities \& social determinants of health. International Social Work, OO(0), 1-6. https://doi.org/10.1177/0020872820944985

Carey, B., \& Glanz, J. (2020, April 23). Hidden outbreaks spread through U.S. cities far earlier than Americans knew, estimates say. New York Times. https://www.nytimes.com/2020/04/23/us/coronavirus-early-outbreaks-cities.html

Center for Disease Control. (2020, July 24). Health equity considerations and racial and ethnic minority groups. CDC. https://www.cdc.gov/coronavirus/2019-ncov/community/healthequity/race-ethnicity.html

Clissold, E., Nylander, D., Watson, C., \& Ventriglio, A. (2020). Pandemics and prejudices. International Journal of Social Psychiatry, 66(5), 421-423. https://doi.org/10.1177/0020764020937873

Cohen, A. (2020, March 13). How Covid-19 layoffs could lead to an increase in crime. Fast Company. https://www.fastcompany.com/90477075/covid-19-layoffs-recession-jobsresearch

Coronavirus (COVID-19) Pandemic inequities in the United States. Health Education \& Behavior, 47(4), 504-508. https://doi.org10.1177/1090198120922942

Das, M. (2020, July 4). Suicide sees a sharp rise in Kolkata amid lockdown, over half are 40 years or younger. https://theprint.in/india/suicides-see-a-sharp-rise-in-kolkata-amid-lockdownover-half-are-40-years-or-younger/453853/

Eaves, L., \& Al-Hindi, K. F. (2020). Intersectional geographies and Covid-19. Dialogue in Human Geography, 10(2), 132-136. https://doi.org/10.1177/2043820620935247

Frazee, G. (2020, March 25). How uninsured patients can get help during covid-19 pandemic. https://www.pbs.org/newshour/health/how-uninsured-patients-can-get-help-during-covid19-pandemic

Garbe, A., Ogurlu, U., Logan, N., \& Cook, P. (2020). Parents' Experiences with Remote Education during COVID-19 School Closures. American Journal of Qualitative Research, 4(3), 4565. https://doi.org/10.29333/ajqr/8471

Global News (2020, May 1). Coronavirus outbreak: New York reports rise in domestic violence incidents amid pandemic. https://globalnews.ca/video/6893244/coronavirus-outbreaknew-york-reports-rise-in-domestic-violence-incidents-amid-pandemic

Goba, K. (2020, April 21). New York City's coronavirus essential workers are overwhelmingly people of color. BuzzFeed. https://www.buzzfeednews.com/article/kadiagoba/coronavirusnew-york-brooklyn-essential-workers-black-poc

Goldmark, A. (2021, December 12). Charts: Whites ride transit less often than everyone else. New York Public Radio. https://www.wnyc.org/story/283287-charts-whites-ride-transit-lessoften-than-everyone-else/

Gordon, S. (2020, May 8). Coronavirus pandemic may lead to 75,000 "deaths of despair" from suicide, drug and alcohol abuse, study say. CBS News. https://www.cbsnews.com/news/coronavirus-deaths-suicides-drugs-alcohol-pandemic$75000 /$ 
Ojha, A.

International Labour Organization. (2020). Covid-19: Stimulating the economy and employment. ILO. https://www.ilo.org/global/about-the-ilo/newsroom/news/WCMS_743036/langen/index.htm

John Hopkins. (2020). Corona Virus Resource Center. John Hopkins University \& Medicine. https://coronavirus.jhu.edu/

Kim, S. J., \& Bostwick, W. (2020). Social vulnerability and racial inequality in Covid-19 deaths in Chicago. Health Education \& Behavior, 47(4), 509-513. https://doi.org10.1177/1090198120929677

Lall, S. \& Wabha, S. (2020, June 18). No urban myth: Building inclusive and sustainable cities in the pandemic recovery. World Bank. https://www.worldbank.org/en/news/immersivestory/2020/06/18/no-urban-myth-building-inclusive-and-sustainable-cities-in-thepandemic-

recovery?cid=ECR_FB_worldbank_EN_EXT\&fbclid=IwAR2scayjX3nONsNS5L52hkoy 6jnUcDqOGBqDjOYIPcSm8CQ9We_W6Rut0EU

Laster Pirtle, W. N. (2020). Racial capitalism: A Fundamental cause of Novel Coronavirus (COVID-19) Pandemic Inequities in the United States. Health Education \& Behavior, 47(4), 504-508. https://journals.sagepub.com/doi/pdf/10.1177/1090198120922942

Leigh, D., \& Kelly, J. (2020, May 24). Coronavirus news: Data finds low income, minorities left homes at height of pandemic. ABC News. https://abc7ny.com/health/data-finds-lowincome-minorities-left-homes-at-height-of-pandemic/6204770/

Link, B. G., \& Phelan, J. (1995). Social conditions as fundamental causes of disease. Journal of Health and Social Behavior, 80-94. https://doi.org/10.2307/2626958

Maciag, M. (2014, February 25). Public Transportation's Demographic Divide. https://www.governing.com/topics/transportation-infrastructure/gov-publictransportation-riders-demographic-divide-for-cities.html

Mallinson, Daniel J. (2020). Cooperation and conflict in state and local innovation during COVID19. American Review of Public Administration, 00(0), 1-8. https://doi.org10.1177/0275074020941699

Mays, J. C., \& Newman, A. (2020, April 8). Virus is twice as deadly for Blacks and Latino people than Whites in NYC. New York Times. https://www.nytimes.com/2020/04/08/nyregion/coronavirus-race-deaths.html

MTA. (2019). Subway and bus ridership for 2019. https://new.mta.info/agency/new-york-citytransit/subway-bus-ridership-2019

New York State. (2020, May 20). Information on novel Corona Virus. NYS. https://www.governor.ny.gov/news/following-spike-domestic-violence-during-covid-19pandemic-secretary-governor-melissa-derosa

NYC Health Department. (2020). Covid-19: Data. NYC Health. https://www1.nyc.gov/site/doh/covid/covid-19-data.page

NYS Health Foundation. (2019, September 10). NYS health statement on 2018 U.S. Census Bureau health insurance data. https://nyshealthfoundation.org/2019/09/10/nyshealth-statementon-2018-u-s-census-bureau-health-insurance-data/

Scott, D. (2020, April 17). Covid-19's devastating toll on Black and Latino Americans, in one chart. Vox. https://www.vox.com/2020/4/17/21225610/us-coronavirus-death-rates-blackslatinos-whites

Semega, Jessica. et al. (2019). Income and poverty in the United States. Washington, D.C.: U.S. Census Bureau. https://www.census.gov/content/dam/Census/library/publications/2019/demo/p60-266.pdf 
Sur, P. (2020, April 16). Under India's caste system, Dalits are considered untouchable. The Coronavirus is intensifying that slur. CNN. https://www.cnn.com/2020/04/15/asia/indiacoronavirus-lower-castes-hnk-intl/index.html

Tarman, B. (2020). Editorial: Reflecting in the shade of pandemic. Research in Social Sciences and Technology, 5(2), i-iv. https://doi.org/10.46303/ressat.05.02.ed

U.S. Census Bureau. (2019, July 1). Quick Fact Check. United States Census Bureau. https://www.census.gov/quickfacts/NY

United Nations Human Rights Office of the High Commissioner. (2020, June 22). Racial discrimination in the context of the COVID-19 crisis. OHCHR. https://www.ohchr.org/Documents/Issues/Racism/COVID19_and_Racial_Discrimination.pdf

Walter-McCabe, H. A. (2020). Coronavirus pandemic calls for an immediate social work response. Social Work in Public Health, 35(3), 69-72. https://www.tandfonline.com/doi/pdf/10.1080/19371918.2020.1751533

Woolhandler, D. U., \& Himmelstein, S. (2020). The U.S. health care system on the eve of the Covid-19 epidemic: A summary of recent evidence on its impaired performance. International Journal of Health Services, $00(0), \quad 1-7$. https://doi.org/10.1177/0020731420937631

Yang, S. (2020, April 19). New York City has logged 248 complaints of Coronavirus discrimination. Wall Street Journal. https://www.wsj.com/articles/new-york-city-haslogged-248-complaints-of-coronavirus-discrimination-11587308400

You, J. (2020). Lesson from South Korea's Covid-19 policy response. American Review of Public Administration, OO(0), 1-8. https://doi.org/10.1177/0275074020943708

\section{Notes on Contributors}

Abin Ojha is an adjunct Assistant Professor of Sociology at York College of the City University of New York. He received his doctoral degree in sociology from Babasaheb Bhimrao Ambedkar (Central) University, Lucknow, India. His current research interests are race and ethnicity, cultural studies, Asian Americans, minority and socio-economic development, and rural cooperatives. 